\title{
Kontribusi Komponen Proses Pendidikan Dan Mutu Lulusan PTAI Terhadap Kepuasan Masyarakat
}

\author{
Abdul Haris Abdullah, S.Ag., M.Pd ${ }^{1}$ \\ Shinta Nento, S.Ag., MPd ${ }^{2}$
}

\begin{abstract}
This study aims to measure the contribution of the education process and the quality of graduates of the PTAI community satisfaction. The method is a survey research, data processing with software SPSS 14 for windows. Results showed there were positive and significant contribution either individually or jointly educational process and quality of graduates of community satisfaction.

Keywords: Community Satisfaction, Contribution Process and Quality Graduates
\end{abstract}

\section{Pendahuluan}

Penelitian ini produknya adalah untuk melihat/mengetahui tingkat kepuasan masyarakat sebagai pengguna result (hasil) keluaran PTAI di pasar kerja. Kepuasan masyarakat dicirikan oleh (kepuasan layanan yang diperoleh, harga atau values, kelengkapan yang dapat dinikmati oleh mereka, serta letak strategis perguruan tinggi). Sebelum melihat produk itu dapat memenuhi kepuasan masyarakat tentu ada komponen-komponen yang turut serta menentukan sebuah produk yakni komponen proses. Dalam penelitian kami membagi komponen proses yang berpengaruh tersebut dalam tiga komponen (Arif Furqan, Swara Cendekia, No. 4 Tahun 1, 2005) yakni komponen proses 1 (kurikulum, silabus, pembelajaran), komponen proses 2 (dosen, mahasiswa, fasilitas), komponen proses 3 (lingkungan, dana pendidikan, kepemimpinan, manajemen). Secara langsung pengaruh ketiga komponen ini tentu memberikan kontribusi kepada mutu lulusan PTAI. Sebutlah salah satu contoh komponen proses 1 (kurikulum, silabus, pembelajaran) secara gamblang dapat kita mengatakannya memilki kontribusi yang penting dalam mencapai mutu keluaran PTAI. Demikian pula

1 Dosen tetap di lingkungan STAIN Manado dan saat ini sedang menyelesaikan program pascasarjana dengan konsentrasi Manajemen Pendidikan di Universitas Negeri Jakarta (UNJ).

2 Calon Dosen dalam Mata Kuliah Statistik Pendidikan di STAIN Manado 
komponen lainnya. Mutu lulusan yang selama ini kita persepsikan sekedar kepentingan individual mahasiswa seperti nilai tinggi dalam prestasi akademik, ternyata dalam pendefinisian secara luas memiliki makna lebih yaitu mutu lulusan sebuah perguruan tinggi yang menentukan adalah kepercayaan masyarakat, loyalitas masyarakat, serta komitmen mereka dalam mempersepsi PTAI dimana anak-anak mereka belajar.

Peningkatan mutu dan daya saing itu sudah menjadi sebuah keniscayaan. Bahkan hal ini telah menjadi komitmen Direktorat Pendidikan Tinggi Islam yang tertuang dalam tujuan pengembangan, yakni menghasilkan lulusan PTAI yang memiliki mutu kompetensi yang diakui luas dan memiliki daya saing tinggi serta mampu berkiprah dalam kehidupan masyarakat.

Peningkatan mutu dan daya saing lulusan tidak akan dapat tercapai bila mutu penyelenggaraan kegiatan akademik tidak dibenahi. Sementara itu, mutu penyelenggaraan kegiatan akademik tidak dapat tercapai jika kesehatan organisasi penyelenggara tidak ditata.

Keterkaitan antara ketiga tahapan strategis tersebut dapat digambarkan sebagai berikut :

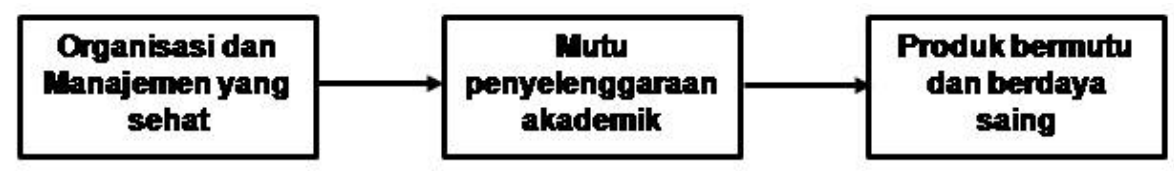

Untuk bisa sukses pendidikan tinggi perlu punya ambisi, yaitu ambisi untuk menjadi lebih baik atau menjadi yang terbaik. Hal ini menyangkut benchmarking dan kompetisi dengan pendidikan tinggi yang lain. Ambisi ini terwujud dalam bentuk keberaniannnya berinvestasi untuk membangun sarana dan prasarana, merekrut staf pengajar yang bermutu, bekerjasama dengan pendidikan tinggi dan lembaga-lembaga yang ternama di dunia, dan lain sebagainya. Tanpa memiliki ambisi untuk menjadikan pendidikan tingginya lebih baik atau bahkan menjadi yang terbaik, tidak akan ada cukup motivasi untuk maju, dan akhirnya hanya tetap merangkak di lapis bawah. 
Mengelola pendidikan tinggi agar berhasil, kita dapat belajar dari perusahaan-perusahaan yang telah berhasil ada beberapa karakteristik yang perlu diadopsi. Pertama, kepekaan terhadap kondisi lingkungan; kedua, pemahaman terhadap keterpaduan dalam sistem dan identitas institusi; ketiga, struktur organisasi yang luwes (fleksibel) tidak kaku agar dapat lebih mudah menyesuaikan dengan kebutuhan lingkungan; dan keempat, konservatisme dalam pengelolaan keuangan.

\section{Tinjauan pustaka}

A. Kepuasan Masyarakat

Dalam penelitian ini yang dimaksud dengan masyarakat adalah pelanggan. Pelanggan menurut Handoko yaitu individu-individu yang melakukan pembelian untuk memenuhi kebutuhan pribadinya atau konsumsi rumah tangga. ${ }^{3}$ Seiring dengan pernyataan Pamitra bahwa pelanggan adalah individu pembuat keputusan yang menyebabkan seseorang harus terlibat atau tidak dalam pembelian suatu produk. ${ }^{4}$ Menurut Supranto pelanggan adalah setiap individu yang menerima suatu jenis barang atau jasa dari beberapa orang lain atau kelompok orang. ${ }^{5}$ Lupiyoadi mendefinisikan Pelanggan adalah seorang individu yang secara continue dan berulang kali datang ke tempat yang sama untuk memuaskan keinginannya dengan memiliki suatu produk atau mendapatkan suatu jasa. ${ }^{6}$

Pelanggan juga berarti individu atau kumpulan individu yang dipengaruhi oleh aspek-aspek eksternal dan internal yang mengarah untuk memilih dan mengkonsumsi barang atau jasa yang diinginkan disebut sebagai pelanggan. ${ }^{7}$ Berbeda menurut Jerome dkk, pelanggan adalah individu yang mengetahui semua fakta dan secara logis membandingkan sejumlah pilihan dalam kaitannya dengan

3 Dharmmesta, Basu Swasta dan Hani Handoko. Edisi Pertama. 1997. Manajemen Pemasaran Analisa Perilaku Konsumen. Yogyakarta: BPFE, h. 12

4 Pamitra, Teddy. 2001. Perilaku Konsumen dan Komunikasi Pemasaran. Bandung: PT Remaja Rosda Karya. h. 11

5 Supranto, J. 2001. Pengukuran Tingkat Kepuasan Pelanggan. Jakarta: PT Asdi Mahasatya. h. 21

6 Lupiyoadi, Rambat. 2001. Edisi Pertama. Manajemen Pemasaran Jasa: Teori dan Praktik. Jakarta: Salemba Empat, 134

7 Umar, Husein. 2003. Metode Riset Perilaku Konsumen Jasa. Jakarta: Gholia Indonesia, h. 11 
biaya dan nilai yang diterima untuk memperoleh kepuasan terbesar dari waktu dan dana yang dikeluarkan. ${ }^{8}$

Menurut Gasperz dalam Nasution pelanggan adalah semua orang yang menuntut perusahaan untuk memenuhi suatu standar kualitas tertentu yang akan memberikan pengaruh pada performansi perusahaan dan manajemen perusahaan. ${ }^{9}$

Dari semua pendapat para ahli diatas dapat disimpukan bahwa pelanggan adalah individu yang melakukan pembelian kebutuhan yang bisa membuat puas dengan membandingkan beberapa aspek seperti harga, standar kualitas barang atau jasa dalam rangka memenuhi kebutuhan pribadi mereka.

Menurut Engel, kepuasan adalah evaluasi paska konsumsi untuk memilih beberapa alternatif dalam rangka memenuhi harapan. ${ }^{10}$ Kotler, menyatakan bahwa perasaan senang atau kecewa seseorang yang muncul setelah membandingkan antara persepsi atau kesannya terhadap kinerja atau hasil dari suatu produk dan harapan-harapannya. ${ }^{11}$ Menurut Supranto, istilah kepuasan pelanggan merupakan label yang digunakan oleh pelanggan untuk meringkas suatu himpunan aksi atau tindakan yang terlihat, terkait dengan produk atau jasa. Contohnya bila seorang pelanggan tersenyum saat melihat produk atau jasa yang sedang dipromosikan maka seseorang itu telah merasakan kepuasan pada produk atau jasa yang dilihat. $^{12}$

Dipertegas oleh Kotler yang menyatakan bahwa kepuasan pelanggan yaitu tingkatan dimana anggapan kinerja (perceived performance) produk akan sesuai dengan harapan seorang pelanggan. ${ }^{13}$ Bila kinerja produk jauh lebih rendah dibandingkan harapan pelanggan, pembelinya tidak puas. Sebaliknya bila kinerja sesuai dengan harapan atau melebihi harapan, pembelinya merasa puas atau merasa puas atau merasa amat gembira. Seiring dengan pendapat diatas Purnomo mengartikan kepuasan pelanggan sebagai "Perbedaan antara harapan dan kinerja atau hasil yang diharapkan”, maksudnya bahwa kepuasan pelanggan tercipta jika

\footnotetext{
Jerome E, dkk. Edisi Ke-lima. 1993. Dasar-Dasar Pemasaran. Jakarta: Erlangga, h. 215

Nasution, M. Nur. 2004. Manajemen Jasa Terpadu. Bogor: Ghalia Indonesia, h. 101

10 Engel, James F. Roger, D. Blacwell. and Minsard, Paul W. 1994. Perilaku Konsumen. Jakarta: Bainarupa Aksara, h. 409

1 Kotler, Philip. 2002. Edisi Milenium. Manajemen Pemasaran. Jakarta: PT Prenhalindo, h. 42

2 Supranto, J. 2001. Opcit, h. 44

13 Kotler, Philip. 2002. Edisi Milenium. Opcit, h. 10
} 
pelanggan merasakan output atau hasil pekerjaan sesuai dengan harapan, atau bahkan melebihi harapan pelanggan. ${ }^{14}$

Oliver dalam Barnes menyatakan kepuasan adalah tanggapan pelanggan atas terpenuhinya kebutuhan yang berarti bahwa penilaian pelanggan atas barang atau jasa memberikan tingkat kenyamanan yang terkait dengan pemenuhan suatu kebutuhan, termasuk pemenuhan kebutuhan yang tidak sesuai harapan atau pemenuhan yang melebihi harapan pelanggan. ${ }^{15}$ Kepusaan pelanggan adalah rangkuman kondisi psikologis yang dihasilkan ketika emosi yang mengelilingi harapan yang tidak cocok dilipat gandakan oleh perasaan-perasaan yang terbentuk dalam pelanggan tentang pengalaman pengkonsumsian. ${ }^{16}$

Menurut Amir kepuasan pelanggan adalah sejauh mana manfaat sebuah produk dirasakan (perceived) sesuai dengan apa yang diharapkan pelanggan. ${ }^{17}$ Kemudian secara sederhana kepuasan pelanggan adalah sebuah produk atau jasa yang dapat memenuhi atau melampaui harapan pelanggan, bisanya pelanggan merasa puas ${ }^{18}$, contohnya seorang pelanggan akan selalu membeli di toko A karena memenuhi semua kebutuhan atau harapannya.

Dari berbagai pendapat yang dilontarkan para ahli bias disimpulkan definisi kepuasan pelanggan adalah respon dari perilaku yang ditunjukkan oleh pelanggan dengan membandingkan antara kinerja atau hasil yang dirasakan dengan harapan. Apabila hasil yang dirasakan dibawah harapan, maka pelanggan akan kecewa, kurang puas bahkan tidak puas, namun sebaliknya bila sesuai dengan harapan, pelanggan akan puas dan bila kinerja melebihi harapan, pelanggan akan sangat puas.

14 Purnomo, Hari. 2003. Edisi Pertama. Pengantar Tehnik Industri. Yogyakarta: Penerbit Graha Ilmu, h. 195

15 Barnes, James G. 2003. Secrets of Customer Relationship Management (Rahasia Manajemen Hubungan Pelanggan). Yogyakarta: Andi, h. 64

16 Peter, J. Paul dan Jerry C Olson. 1996. Edisi Keempat. Consumer Behavior (perilaku konsumen dan strategi pemasaran). Jakarta: Erlangga, h. 157

17 Amir, M. Taufik. 2005. Edisi Pertama. Dinamika Pemasaran Jelajahi dan Rasakan. Jakarta: PT Raja Grafindo Persada, h. 13

18 Gerson, Richard F. 2002. Mengukur Kepuasan Pelanggan. Jakarta: Penerbit PPM, h. 5 


\section{B. Komponen proses}

\section{Lingkungan}

Gilmer (1984) menyatakan bahwa lingkungan organisasi merupakan keadaan di dalam organisasi dimana setiap anggotanya saling berinteraksi, membatasi dan mengenali satu sama lain serta menentu-kan kualitas kerja sama, pengembangan anggota organisasi dan efisiensi yang akan mengubah tujuan menjadi hasil.

Kolb dkk. (1984) mendefinisikan lingkungan organisasi diperankan oleh tujuh aspek yaitu komformitas, tanggungjawab, standart, penghargaan, kejelasan organi-sasi, kehangatan dan dukungan dan kepemimpinan.

Gibson dkk. (1994) menggunakan istilah lingkungan organisasi untuk menggambarkan lingkungan atau situasi dari organisasi. Istilah lingkungan organisasi dapat juga dipergunakan untuk menggambarkan iklim psikologis atau kepribadian organisasi

Penelitian ini menggunakan konsep dari Gibson dkk. (1994) bahwa lingkungan organisasi adalah sifat lingkungan kerja atau lingkungan psikologis dalam organisasi yang dirasakan oleh para pekerja atau anggota organisasi dan dianggap dapat mempengaruhi sikap dan perilaku pekerja terhadap pekerjaanya. Penelitian ini menggunakan tujuh dimensi dari Kolb (1984) untuk mengukur lingkungan organisasi yaitu komformitas, tanggung jawab, standar, pengahargaan, kejelasan organisasi, kehangatan dan dukungan dan kepemimpinan.

Menurut Kelner (1998) lingkungan organisasi mempengaruhi kepuasan kerja. Ia menyatakan bahwa lingkungan organisasi yang kondusif dan hubungan kerja yang baik dapat meningkatkan kepuasan kerja karyawan.

Sinungan (1987) berpendapat bahwa lingkungan organisasi yang sehat dapat mendorong sikap keterbukaan baik dari pihak karyawan maupun pihak pengusaha (atau dengan kata lain terciptanya komformitas hubungan karyawan dan pengusaha), sehingga mampu menumbuhkan kepuasan kerja yang akan mengakibatkan peningkatan produksi dan produktivitas kerja. 


\section{Dana}

Mengapa kita harus memahami sumber dan penggunaan dana? Pemahaman ini diperlukan, agar kita bisa mengelola keuangan dengan benar, dan tidak terjadi missmatch antara sumber dan penggunaan dana. Pemahaman tentang sumber dan penggunaan dana ini, tak hanya perlu untuk pimpinan, atau orang yang bertanggung jawab di bidang keuangan, namun juga diperlukan bagi semua anggota organisasi agar bisa mengelola keuangan secara benar.

Apabila kita melihat sebuah laporan keuangan, selain menilai perkembangan laporan keuangan tersebut, serta melihat angka ratio-ratio keuangan perusahaan, maka kita juga perlu melihat apakah dana yang ditanam dalam perusahaan tersebut telah digunakan sesuai tujuannya. Bagaimana cara mengetahui hal tersebut? Pertama-tama harus mengetahui sumber dan penggunaan dana, apakah dana yang berasal dari dana jangka pendek, digunakan untuk keperluan jangka pendek (missal; kepentingan organisasi), serta telah tertanam dalam bentuk ada harapan nilai kembali, serta tidak digunakan untuk keperluan investasi baik profit ataupun non-profit.

\section{Kepemimpinan}

Kepemimpinan adalah sebuah keputusan dan lebih merupakan hasil dari proses perubahan karakter atau transformasi internal dalam diri seseorang. Kepemimpinan bukanlah jabatan atau gelar, melainkan sebuah kelahiran dari proses panjang perubahan dalam diri seseorang. Ketika seseorang menemukan visi dan misi hidupnya, ketika terjadi kedamaian dalam diri (inner peace) dan membentuk bangunan karakter yang kokoh, ketika setiap ucapan dan tindakannya mulai memberikan pengaruh kepada lingkungannya, dan ketika keberadaannya mendorong perubahan dalam organisasinya, pada saat itulah seseorang lahir menjadi pemimpin sejati

Kepemimpinan meliputi proses mempengaruhi dalam menentukan tujuan organisasi, memotivasi perilaku pengikut untuk mencapai tujuan, mempengaruhi untuk memperbaiki kelompok dan budayanya. Kepemimpinan mempunyai kaitan yang erat dengan motivasi. Hal tersebut dapat dilihat dari keberhasilan seorang 
pemimpin dalam menggerakkan orang lain dalam mencapai tujuan yang telah ditetapkan sangat tergantung kepada kewibawaan, dan juga pimpinan itu dalam menciptakan motivasi dalam diri setiap orang bawahan, kolega, maupun atasan pimpinan itu sendiri.

Hubungan antara perilaku kepemimpinan dengan kinerja. Kepemimpinan adalah suatu proses dimana individu mempengaruhi kelompok untuk mencapai tujuan umum. Pengertian ini lebih lanjut mengandung arti bahwa kepemimpinan itu adalah kemampuan untuk menanamkan keyakinan dan memperoleh dukungan dari anggota organisasi untuk mencapai tujuan organisasi. Dari aspek karakteristik dibedakan antara karakteristik pemimpin (leader) dengan karkateristik manajer. Bahwa karakteristik pemimpin di Abad XXI adalah: Innovates (menciptakan sesuatu yang baru); An original (asli dari pemimpin); Develops (mengembangkan); Focuses on people (terkonsentrasi pada manusia); Inspires trust (menghidupkan rasa percaya); Long-range perspective (memiliki prespektif jangka panjang); Asks what and why (ia menanyakan apa dan mengapa); Eye on the horizon (berpandangan sama pada sesamanya); Originates (memiliki keaslian); Challenges the Status quo (menentang kemapanan); Own person (mengakui tanggung jawab ada pada pemimpin); Does the right thing (mengerjakan yang benar). Pemimpin memiliki karakteristik selalu memiliki upaya untuk menciptakan hal yang baru (selalu berinovasi).

Setiap pemimpin memiliki gaya kepemimpinan, ada kalanya pemimpin tidak memberi kesempatan pada bawahannya untuk bertanya ataupun minta penjelasan (Authoritarian), ada kalanya pemimpin memberi kesempatan bawahan untuk berdiskusi, bertanya (Democratic), dan ada kalanya pemimpin itu membiarkan kondisi yang ada terserah pada bawahan (Laissez -fair).

Kajian terhadap teori kepemimpinan terus berkembang pada teori Sifat (Trait Theories), teori Kelompok dan Tukar Menukar (Group and Exchanges Theories), teori Contingency, teori Jalur dan Tujuan (Path-Goal Leadership Theory), toeri Kepemimpinan Karismatik (Charismatic Leadership Theories), teori Kepemimpinan Transformasional (Transformational Leadership Theory). 
Pembahasan kepemimpinan juga dikaji tentang gaya kepemimpinan (Leadership Style). Studi klasik tentang teori kepemimpinan telah mengembangkan gaya kepemimpinan yang kontinum Boss-Centered dan Employee Centered. Komponen dari Boss-Centered (meliputi: Theory X, Autocratic, Production Centered, Close, Initiating Structure, Task-directed, Directive). Sedangkan Employee Centered memiliki komponen: Theory $Y$, Democratic, Employee-Centered, General, Consideration, Human relations, Supportive, Participative. Gaya kepemimpinan tersebut telah mendasari teori Tannebaum and Schmidt Continuum of Leadership Behavior.

Gaya kepemimpinan yang mendasarkan pada dua demensi yaitu perhatian terhadap tugas (Concern for Task) dan perhatian terhadap karyawan (Concern for People) telah melahirkan teori gaya kepemimpinan yang terkenal dengan The Blake and Mouton Managerial Grid. Berikutnya berkembang pula gaya kepemimpinan situasional yang dikembangkan oleh Harsey dan Blanchard yang kemudian dikenal dengan Harsey dan Blanchard's Situational Leadership Model.

Sebagai pemimpin, manajer ataupun pimpinan memiliki peran (role), kegiatan, dan skill. Pimpinan memiliki peran Interpersonal Roles, Informational Roles, Decisional Roles. Sedangkan kegiatan mereka adalah: Routine Communication, Traditional Management, Networking, dan Human Resource Management. Serta skill bagi pemimpin adalah: (1) komunikasi verbal, (2) mengatur waktu dan mengelola stress, (3) melakukan pengambilan keputusan, (4) mengakui, menjelaskan, dan memecahkan permasalahan, (5) memotivasi dan mempengaruhi orang lain, (6) mendelegasikan wewenang, (7) menetapkan tujuan dan menjelaskan visi, (8) memiliki kesadaran diri, (9) membangun kerja tim, dan (10) memanaj konflik.

Kinerja yang sering disebut dengan performance juga disebut result yang berarti apa yang telah dihasilkan oleh individu karyawan. Istilah yang lain adalah human output yang dapat diukur dari productivity, absence, turnover, citizenship, dan satisfaction. Kinerja pada individu juga disebut dengan job performance, work outcome, task performance. Result dipengaruhi oleh kinerja organisasi (organizational performance) yang komponennya terdiri Organizational 
Development, Compensation Plan, Communication System, Managerial Style, Organization Structure, Policies and Procedures. Organizational performance tersebut merupakan strategi (program) dari setiap departemen sumberdaya manusia dan dari organisasi. Ini berarti result (kinerja) dipengaruhi oleh strategi organisasi. Sehubungan dengan strategy ditentukan oleh pemimpin organisasi dan strategy dipengaruhi oleh budaya organisasi maka kinerja organisasi dipengaruhi pula oleh budaya organisasi, dan juga dipengaruhi oleh perilaku kepemimpinan.

Hubungan antara perilaku kepemimpinan dengan kepuasan kerja. Kepuasan kerja adalah suasana psikologis tentang perasaan menyenangkan atau tidak menyenangkan terhadap pekerjaan mereka. Kepuasan kerja merupakan bangunan unidimensional, dimana seseorang memiliki kepuasan umum atau ketidakpuasan dengan pekerjaannya.

Kepuasan kerja sebagai satu acuan dari orientasi yang efektif seseorang pegawai terhadap peranan mereka pada jabatan yang dipegangnya saat ini. Sikap yang positif terhadap pekerjaan secara konsepsi dapat dinyatakan sebagai kepuasan kerja dan sikap negatif terhadap pekerjaan sama dengan ketidakpuasan. Definisi ini menjelaskan bahwa kepuasan kerja sebagai perasaan seseorang pegawai mengenai pekerjaannya. Secara sederhana, job satisfaction dapat dikatakan sebagai apa yang membuat orang-orang menginginkan dan menyenangi pekerjaan. Apa yang membuat mereka bahagia dalam pekerjaannya atau keluar dari pekerjaanya.

Sumber kepuasan kerja terdiri atas pekerjaan yang menantang, imbalan yang sesuai, kondisi/ lingkungan kerja yang mendukung, dan rekan kerja yang mendukung. Dalam penelitian menyebutkan bahwa faktor yang mempengaruhi kepuasan kerja pegawai secara signifikan adalah : faktor yang berhubungan dengan pekerjaan, dengan kondisi kerja, dengan teman sekerja, dengan pengawasan oleh pimpinan, dengan promosi jabatan dan dengan gaji. 


\section{MUTU LULUSAN}

Mutu dapat dilihat dari indikator-indikatornya yakni: Kepercayaan pelanggan, Loyalitas Pelanggan, dan Komitmen.

\section{Kepercayaan}

Definisi kepercayaan menurut Schurr dan Ozane (1988) kepercayaan adalah suatu keyakinan bahwa pernyataan pihak lain dapat diandalkan untuk memenuhi kewajibannya. Ketidak percayaan bisa terjadi sejalan dengan minimnya informasi dalam perencanaan dan pengukuran kinerja. Rasa percaya atau tidak percaya seseorang yang muncul dalam perilakunya ditentukan oleh faktor-faktor seperti informasi, pengaruh, dan pengendaliaan. Kepercayaan akan meningkat bila informasi yang diterima dinilai akurat, relevan, dan lengkap.

Tingkat kepereayaan juga dipengaruhi oleh pengalaman di masa lalu, pengalaman positif yang konsisten di masa lalu dengan suatu pihak akan meningkatkan rasa saling percaya sehingga akan menumbuhkan harapan akan hubungan yang baik di masa yang akan datang. Berikut beberapa pendapat mengenai kepercayaan menurut beberapa ahli.

Menurut Berry (I998); Moorman, Deshpande, dan Zaltman (1993); Morgan dan Hunt (1994) kepercayaan secara umum dipandang sebagai komponen penting untuk hubungan yang sukses, Sedangkan, Crosby, Evan, dan Cowles (1990) cenderung menekankan kepercayaan sebagai percaya terhadap kejujuran dan integritas kelompok yang lain, seperti pada seorang penjual. Hal yang lain diungkapkan oleh Gwinner, Gremler, dan Bltner (1998) dengan menggunakan deflntsi kepercayaan yang mirip, mereka menemukan keuntungan psikologis rasa percaya diri dan kepercayaan lebih penting daripada perlakuan istimewa atau keuntungan sosial dalam hubungan konsumen dengan jasa pelayanan.

Dari beberapa definisi di atas, maka dapat disimpulkan bahwa kepercayaan merupakan salah satu kunci terpenting untuk menjalin hubungan yang baik dengan konsumen. Hubungan lersehut dapat berlanjut jika perusahaan yang dipercaya mampu memenuhi kebutuhan dan keinginan konsumen. 


\section{Konsep Kepercayaan}

Menurul Soetomo (2002) ada lima tindakan yang menunjukkan suatu kepercayaan: (1) menjaga hubungan. (2) menerima pengaruh, (3) terbuka dalam komuniknsi, (4) mengurangi pengavvasan, dan (5) kesabaran akan faham oportunis. Moorman, Zaltman, dan Deshpande dalam Zulganef (2002), berhasil mengungkapkan bahwa keterhubungan antara dua pihak yang melakukan pertukaran, dalarm hal ini pengguna informasi penelitian dan para peneliti. secara langsung dipengaruhi oleh kepercayaan terhadap peneliti, kualitas interaksi dengan peneliti.

Definisi-definisi tersebut digambarkan dalam pandangan klasik bahwa kepercayaan merupakan harapan umum yang dipertahankan oleh individu yang ucapan dari satu pihak ke pihak lainnya dapat dipercaya. Kepercayaan merupakan variabel terpenting dalam membangun hubungan jangka panjang antara satu pihak dengan pihak lainnya.

Pengukuran kepercayaan menurut Zulganef (2002) adalah: kinerja perusahaan secara keseluruhan memenuhi harapan, pelayanan yang diberikan perusahaan secara konsisten terjaga kualitasnya. percaya bahwa perusahaan tersebut akan bertahan lama.

Menurat Ramadania adapun indikator kepercayaan adalah sebagai berikut: (2003:39)

a. Reputasi yang dimiliki produk

b. Keamanan dan kenyamanan dalam menggunakan produk c. Manfaat yang ada pada produk

\section{Loyalitas}

Loyalitas secara harfiah diartikan kesetiaan, yaitu kesetiaan seseorang terhadap suatu objek. Mowen dan Minor (1998) mendefinisikan loyalitas sebagai kondisi di mana pelanggan mempunyai sikap positif terhadap suatu merek, mempunyai komitmen pada merek tersebut, dan bermaksud meneruskan pembeliannya di masa mendatang. Loyaltas menunjukkan kecenderungan pelanggan untuk menggunakan suatu merek tertentu dengan tingkat konsistensi 
yang tinggi (Dharmmesta, 1999). Ini berarti loyalitas selalu berkaitan dengan preferensi pelanggan dan pembelian aktual.

Definisi loyalitas dari pakar yang disebutkan di atas berdasarkan pada dua pendekatan, yaitu sikap dan perilaku. Dalam pendekatan perilaku, perlu dibedakan antara loyalitas dan perilaku beli ulang. Perilaku beli ulang dapat diartikan sebagai perilaku pelanggan yang hanya membeli suatu produk secara berulang-ulang, tanpa menyertakan aspek perasaan dan pemilikan di dalamnya. Sebaliknya loyalitas mengandung aspek kesukaan pelanggan pada suatu produk. Ini berarti bahwa aspek sikap tercakup di dalamnya.

Loyalitas berkembang mengikuti tiga tahap, yaitu kognitif, afektif, dan konatif. Biasanya pelanggan menjadi setia lebih dulu pada aspek kognitifnya, kemudian pada aspek afektif, dan akhirnya pada aspek konatif. Ketiga aspek tersebut biasanya sejalan, meskipun tidak semua kasus mengalami hal yang sama.

\section{1) Tahap pertama: Loyalitas Kognitif}

Pelanggan yang mempunyai loyalitas tahap pertama ini menggunakan informasi keunggulan suatu produk atas produk lainnya. Loyalitas kognitif lebih didasarkan pada karakteristik fungsional, terutama biaya, manfaat dan kualitas. Jika ketiga faktor tersebut tidak baik, pelanggan akan mudah pindah ke produk lain. Pelanggan yang hanya mengaktifkan tahap kognitifnya dapat dihipotesiskan sebagai pelanggan yang paling rentan terhadap perpindahan karena adanya rangsangan pemasaran (Dharmmesta, 1999).

\section{2) Tahap kedua: Loyalitas Afektif}

Sikap merupakan fungsi dari kognisi pada periode awal pembelian (masa sebelum konsumsi) dan merupakan fungsi dari sikap sebelumnya ditambah dengan kepuasan di periode berikutnya (masa setelah konsumsi). Munculnya loyalitas afektif ini didorong oleh faktor kepuasan yang menimbulkan kesukaan dan menjadikan objek sebagai preferensi. Kepuasan pelanggan berkorelasi tinggi dengan niat pembelian ulang di waktu mendatang. Pada loyalitas afektif, kerentanan pelanggan lebih banyak terfokus pada tiga faktor, yaitu ketidakpuasan dengan merek yang ada, persuasi dari pemasar maupun pelanggan merek lain, dan upaya mencoba produk lain (Dharmmesta, 1999). 


\section{3) Tahap ketiga: Loyalitas Konatif}

Konasi menunjukkan suatu niat atau komitmen untuk melakukan sesuatu. Niat merupakan fungsi dari niat sebelumnya (pada masa sebelum konsumsi) dan sikap pada masa setelah konsumsi. Maka loyalitas konatif merupakan suatu loyalitas yang mencakup komitmen mendalam untuk melakukan pembelian. Hasil penelitian Crosby dan Taylor (1983) yang menggunakan model runtutan sikap: keyakinan - sikap - niat memperlihatkan komitmen untuk melakukan (niat) menyebabkan preferensi pemilih tetap stabil selama 3 tahun.

Jenis komitmen ini sudah melampaui afek. Afek hanya menunjukkan kecenderungan- motivasional, sedangkan komitmen untuk melakukan menunjukkan suatu keinginan untuk melaksanakan tindakan. Keinginan untuk membeli ulang atau menjadi loyal itu hanya merupakan tindakan yang terantisipasi tetapi belum terlaksana. Untuk melengkapi runtutan loyalitas, satu tahap lagi ditambahkan pada model kognitif-afektif-konatif, yaitu loyalitas tindakan.

\section{4) Tahap keempat; Loyalitas Tindakan}

Aspek konatif atau niat untuk melaku-kan berkembang menjadi perilaku dan tindakan. Niat yang diikuti oleh motivasi, merupakan kondisi yang mengarah pada kesiapan bertindak dan keinginan untuk mengatasi hambatan dalam melakukan tindakan tersebut. Jadi loyalitas itu dapat menjadi kenyataan melalui beberapa tahapan, yaitu pertama sebagai loyalitas kognitif, kemudian loyalitas afektif, dan loyalitas konatif, dan akhirnya sebagai loyalitas tindakan.

Pelanggan yang terintegrasi penuh pada tahap loyalitas tindakan dapat dihipotesiskan sebagai pelanggan yang rendah tingkat kerentanannya untuk berpindah ke produk lain. Dengan kata lain, loyalitas tindakan ini hanya sedikit bahkan sama sekali tidak memberi peluang pada pelanggan untuk berpindah ke produk lain. Pada loyalitas konasi dan tindakan, kerentanan pelanggan lebih terfokus pada faktor persuasi dan keinginan untuk mencoba produk lain. 


\section{Metode Penelitian}

Jenis penelitian ini menggunakan metode penelitian survei dengan pendekatan penelitian kuantitatif. Penelitian survei yang dimaksud adalah bersifat menjelaskan hubungan kausal dan pengujian hipotesis. Seperti dikemukakan Masri S. (1995:21) penelitian survei dapat digunakan untuk maksud: (1) penjajagan (eksploratif), (2) deskriptif, (3) penjelasan (eksplanatory atau confirmatory), yakni menjelaskan hubungan kausal dan pengujian hipotesis; (4) evaluasi, (5) prediksi atau meramalkan kejadian tertentu di masa yang akan datang (6) penelitian operasional, dan (7) pengembangan indikator-indikator sosial.

Jenis penelitian survei ini memfokuskan pada pengungkapan hubungan kausal antar variabel, yaitu suatu penelitian yang diarahkan untuk menyelidiki hubungan sebab berdasarkan pengamatan terhadap akibat yang terjadi, dengan tujuan memisahkan pengaruh langsung dan pengaruh tidak langsung sesuatu variabel penyebab terhadap variabel akibat. Variabel sebab-akibat tersebut adalah Komponen Proses 1 (X1), Komponen Proses 2 (X2, Komponen Proses 3 (X3), Mutu Lulusan (X4) terhadap Kepuasan Masyarakat (Y).

Langkah-langkah atau prosedur pengolahan data yang dilakukan dalam penelitian ini adalah sebagai berikut: (1) menyeleksi data agar dapat diolah lebih lanjut, yaitu dengan memeriksa jawaban responden sesuai dengan kriteria yang telah ditetapkan; (2) menentukan bobot nilai untuk setiap kemungkinais jawaban pada setiap item variabel penelitian dengan menggunakan skala penilaian yang telah ditentukan, kemudian menentukan skornya; (3) melakukan analisis secara deskriptif, untuk mengetahui kecenderungan data. Dari analisis ini dapat diketahui rata-rata, median, standar deviasi dan varians data dari masing-masing variabel; (4) melakukan uji korelasi, regresi dilanjutkan path analysis.

\section{Menguji dengan Analisis Korelasi sederhana dan Ganda}

Mengetahui hubungan antara variable X1 dengan X4, X1 dengan $\mathrm{Y}, \mathrm{X} 2$ dengan $\mathrm{X} 4, \mathrm{X} 2$ dengan $\mathrm{Y}$ dan $\mathrm{X} 3$ dengan $\mathrm{X} 4$, dan $\mathrm{X} 3$ dengan $\mathrm{X} 4, \mathrm{X} 3$ dengan $\mathrm{Y}$, dan X4 dengan Y digunakan teknik korelasi. Analisis Korelasi yang digunakan adalah (PPM) Pearson Product Moment, dengan rumus: 


$$
r_{X Y}=\frac{n\left(\sum X Y\right)-\left(\sum X\right) \cdot\left(\sum Y\right)}{\sqrt{\left\{n \cdot \sum X^{2}-\left(\sum X\right)^{2}\right\} \cdot\left\{n \cdot \sum Y^{2}-\left(\sum Y\right)^{2}\right\}}}
$$

Korelasi PPM dilambangkan (r) dengan ketentuan nilai $r$ tidak lebih dari harga $(-1<\mathrm{r}<=1)$. Apabila nilai $\mathrm{r}=-1$ artinya korelasinya negatif sempurna; $\mathrm{r}=$ 0 artinya tidak ada korelasi; dan $r=1$ berarti korelasinya sangat kuat. Sedangkan arti harga $r$ akan dikonsultasikan dengan Tabel interpretasi Nilai $r$ sebagai berikut:

Interpretasi Koefisiēn Korelasi Nilai r

\begin{tabular}{|c|l|}
\hline Interval Koefisien & Tingkat Hubungan \\
\hline $0,80-1,000$ & Sangat Kuat \\
$0,60-0,799$ & Kuat \\
$0,40-0,599$ & Cukup Kuat \\
$0,20-0,399$ & Rendah \\
$0,00-0,199$ & Sangat Rendah \\
\hline
\end{tabular}

Sumber: Riduwan (2005:138)

Pengujian lanjutan yaitu uji signifikansi yang berfungsi apabila peneliti ingin mencari makna hubungan variabel X terhadap Y, maka hasil korelasi PPM tersebut diuji dengan Uji Signifikansi dengan rumus:

$$
t_{\text {hitung }}=\frac{r \sqrt{n-2}}{\sqrt{1-r^{2}}} \quad \begin{aligned}
\text { Dimana: } \mathrm{t}_{\text {hitung }} & =\text { Nilai } \mathrm{t} \\
\mathrm{r} & =\text { Nilai Koefisien Korelasi } \\
\mathrm{n} & =\text { Jumlah sampel }
\end{aligned}
$$

Selanjutnya untuk menyatakan besar kecilnya sumbangan variabel $\mathrm{X}$ terhadap $\mathrm{Y}$ dapat ditentukan dengan rumus koefisien diterminan. Koefisien determinasi adalah kuadrat dari koefisien korelasi PPM yang dikalikan dengan 100\%. Dilakukan untuk mengetahui seberapa besar variabel X mempunyai kontribusi atau ikut menentukan variabel Y. Derajat koefisien determinasi dicari dengan menggunakan rumus:

$$
K P=r^{2} \times 100 \%
$$

Dimana $:$ KP $=$ Nilai Koefisien Diterminan $\mathrm{r}=$ Nilai Koefisien Korelasi.

Mengetahui hubungan antara variabel Xi dan X2 secara bersama-sama terhadap variabel Y digunakan rumus korelasi ganda sebagai berikut.

$$
R_{X 1 . X 2 . Y}=\sqrt{\frac{r_{X 1 . Y}^{2}+r_{X 2 . Y}^{2}-2\left(r_{X 1 . Y}\right) \cdot\left(r_{X 2 . Y}\right) \cdot\left(r_{X 1 . X 2}\right)}{1-r_{X 1 . X 2}^{2}}}
$$




\section{Menguji dengan Analisis Regresi Sederhana dan Ganda}

Uji Regresi, digunakan untuk mencari pengaruh antar variable. Dalam uji ini digunakan regresi linier dengan regresi ganda dengan rumus sebagai berikut:

Persamaan regresi dirumuskan: $\hat{Y}=a+b X$

Dimana:

$\hat{Y}=$ (baca $\mathrm{Y}$ topi) subjek variabel terikat yang diproyeksikan

$\mathrm{X}=$ Variabel bebas yang mempunyai nilai tertentu untuk diprediksikan

a = Nilai konstanta harga $\mathrm{Y}$ jika $\mathrm{X}=\mathrm{O}$

$\mathrm{b}=$ Nilai arah sebagai penentu ramalan (prediksi) yang menunjukkan pening-katan $(+)$ atau nilai penurunan $(-)$ variabel Y

$$
b=\frac{n \cdot \Sigma X Y-. \Sigma X \cdot \Sigma Y}{n \cdot \Sigma X^{2}-(\Sigma X)^{2}} \quad a=\frac{. \Sigma Y-b \cdot \Sigma X}{n .}
$$

Persamaan regresi ganda dirumuskan:

$\hat{Y}=a+b_{1} X_{1}+b_{2} X_{2}$

\section{Menguji dengan Analisis Jalur (path Analysis)}

Dalam rangka kepentingan penelitian maka kami sebagai peneliti tidak lagi mengikutkan pengujian korelasi ataupun regresi dalam penulisan ini, tetapi akan lebih focus kepada pengujian jalur (path analysis).

Teknik analisis jalur (Path Analysis). Analisis ini akan digunakan dalam menguji besarnya kontribusi yang ditunjukkan oleh keoefisien jalur pada setiap diagram jalur dari hubungan kausal antar variabel X1, X2, X3, dan X4 terhadap Y. Untuk mengetahui derajat hubungan antar variable. Al Rasyid dalam Sitepu (1994:24) mengatakan bahwa dalam penelitian sosial tidak semata-mata hanya mengungkapkan hubungan variabel sebagai terjemahan statistik dari hubungan antara variabel alami, tetapi terfokus pada upaya untuk mengungkapkan hubungan kausal antar variabel. 


\section{Hasil Penelitian Dan Pembahasan}

Correlations

\begin{tabular}{|c|c|c|c|c|c|c|}
\hline & & $\begin{array}{c}\text { Komponen } \\
\text { Proses } 1\end{array}$ & $\begin{array}{l}\text { Komponen } \\
\text { Proses } 2\end{array}$ & $\begin{array}{l}\text { Komponen } \\
\text { Proses } 3\end{array}$ & $\begin{array}{c}\text { Mutu } \\
\text { Lulusan }\end{array}$ & $\begin{array}{c}\text { Kepuasan } \\
\text { Masyarakat }\end{array}$ \\
\hline \multirow[t]{3}{*}{ Komponen Proses 1} & $\begin{array}{c}\text { Pearson } \\
\text { Correlation }\end{array}$ & 1 & $.641^{*}$ & $.772^{* *}$ & $.831^{* *}$ & $.950^{* *}$ \\
\hline & Sig. (2-tailed) & & .025 & .003 & .001 & .000 \\
\hline & $\mathrm{N}$ & 12 & 12 & 12 & 12 & 12 \\
\hline \multirow[t]{3}{*}{ Komponen Proses 2} & $\begin{array}{c}\text { Pearson } \\
\text { Correlation }\end{array}$ & $.641^{*}$ & 1 & $.887^{* *}$ & $.829^{* *}$ & $.705^{*}$ \\
\hline & Sig. (2-tailed) & .025 & & .000 & .001 & .010 \\
\hline & $\mathrm{N}$ & 12 & 12 & 12 & 12 & 12 \\
\hline \multirow[t]{3}{*}{ Komponen Proses 3} & $\begin{array}{c}\text { Pearson } \\
\text { Correlation }\end{array}$ & $.772^{* *}$ & $.887^{* *}$ & 1 & $.834^{* *}$ & $.881^{* *}$ \\
\hline & Sig. (2-tailed) & .003 & .000 & & .001 & .000 \\
\hline & $\mathrm{N}$ & 12 & 12 & 12 & 12 & 12 \\
\hline \multirow[t]{3}{*}{ Mutu Lulusan } & $\begin{array}{c}\text { Pearson } \\
\text { Correlation }\end{array}$ & $.831^{* *}$ & $.829^{* *}$ & $.834^{* *}$ & 1 & $.892^{* *}$ \\
\hline & Sig. (2-tailed) & .001 & .001 & .001 & & .000 \\
\hline & $\mathrm{N}$ & 12 & 12 & 12 & 12 & 12 \\
\hline \multirow[t]{3}{*}{ Kepuasan Masyarakat } & $\begin{array}{c}\text { Pearson } \\
\text { Correlation }\end{array}$ & $.950^{* *}$ & $.705^{*}$ & $.881^{* *}$ & $.892^{* *}$ & 1 \\
\hline & Sig. (2-tailed) & .000 & .010 & .000 & .000 & \\
\hline & $\mathrm{N}$ & 12 & 12 & 12 & 12 & 12 \\
\hline
\end{tabular}

*. Correlation is significant at the 0.05 level (2-tailed).

**. Correlation is significant at the 0.01 level (2-tailed).

\section{Pengujian Hipotesis}

\section{a) Hipotesis 1}

"Terdapat kontribusi komponen proses 1(X1) (kurikulum, silabus, \& pembelajaran) melalui mutu lulusan(X4) (kepercayaan, loyalitas \& komitmen) terhadap kepuasan masyarakat(Y) (layanan, harga, letak, \& lengkap)"

$$
\begin{aligned}
& \text { Ha }: \text { PYX1 = PYX4 \# } 0 \\
& \text { Ho }: \text { PYX1 }=\text { PYX4 = }
\end{aligned}
$$

Dari hasil pengolahan data program SPSS 17 for windows terlihat pada table berikut, koefisien jalur yang diperoleh adalah : 
ANOVA $^{b}$

\begin{tabular}{|ll|r|r|r|r|r|}
\hline Model & & Sum of Squares & Df & Mean Square & F & \multicolumn{1}{c|}{ Sig. } \\
\hline 1 & Regression & 1806.257 & 2 & 903.128 & 65.863 & $.000^{\mathrm{a}}$ \\
& Residual & 123.410 & 9 & 13.712 & & \\
& Total & 1929.667 & 11 & & & \\
\hline
\end{tabular}

a. Predictors: (Constant), Mutu Lulusan (X4), Komponen Proses 1 (X1)

b. Dependent Variable: Kepuasan Masyarakat (Y)

\begin{tabular}{|c|c|c|c|c|c|c|}
\hline \multicolumn{7}{|c|}{ Coefficients $^{a}$} \\
\hline \multirow{2}{*}{\multicolumn{2}{|c|}{ Model }} & \multicolumn{2}{|c|}{ Unstandardized Coefficients } & \multirow{2}{*}{$\begin{array}{c}\begin{array}{l}\text { Standardized } \\
\text { Coefficients }\end{array} \\
\text { Beta }\end{array}$} & \multirow[b]{2}{*}{$\mathrm{t}$} & \multirow[b]{2}{*}{ Sig. } \\
\hline & & $\mathrm{B}$ & Std. Error & & & \\
\hline \multirow[t]{3}{*}{1} & (Constant) & -.581 & 7.450 & & -.078 & .940 \\
\hline & Komponen Proses 1 (X1) & .629 & .141 & .673 & 4.450 & .002 \\
\hline & Mutu Lulusan (X4) & .389 & .177 & .333 & 2.197 & .056 \\
\hline
\end{tabular}

a. Dependent Variable: Kepuasan Masyarakat (Y)

Model Summary

\begin{tabular}{|c|c|c|c|c|c|c|c|c|c|}
\hline \multirow[b]{2}{*}{ Model } & \multirow[b]{2}{*}{$\mathrm{R}$} & \multirow[b]{2}{*}{ R Square } & \multirow[b]{2}{*}{$\begin{array}{l}\text { Adjusted } \\
\text { R Square }\end{array}$} & \multirow[b]{2}{*}{$\begin{array}{l}\text { Std. Error of } \\
\text { the Estimate }\end{array}$} & \multicolumn{5}{|l|}{ Change Statistics } \\
\hline & & & & & R Square Change & F Change & df1 & $\mathrm{df} 2$ & $\begin{array}{l}\text { Sig. F } \\
\text { Change }\end{array}$ \\
\hline 1 & $.967^{\mathrm{a}}$ & .936 & .922 & 3.70300 & .936 & 65.863 & 2 & 9 & .000 \\
\hline
\end{tabular}

a. Predictors: (Constant), Mutu Lulusan (X4), Komponen Proses 1 (X1)

Tabel anova diperoleh nilai $\mathrm{F}$ untuk sebesar 65,863 dengan nilai probabilitas $(\mathrm{sig})=0,000$. Karena nilai sig $<0,05$, maka keputusannya adalah HO di tolak dan Ha diterima artinya komponen proses 1(X1) dengan Mutu Lulusan (X4) secara bersama-sama berpengaruh terhadap Kepuasan Masyarakat (Y).

Besarnya koefisien determinan $\mathrm{R}_{\mathrm{square}}$ atau $\mathrm{R}_{\mathrm{yx} 1 \mathrm{x} 4}=0,922=92,2 \%$ (lihat tabel summary) dan dan besarnya pengaruh variable lain pye1 $=\sqrt{-0,922}=0,078=$ $7,8 \%$.

\section{b) Hipotesis 2}

“Terdapat kontribusi komponen proses 2(X2) (dosen, mahasiswa, \& fasilitas) melalui mutu lulusan(X4) (kepercayaan, loyalitas \& komitmen) terhadap kepuasan masyarakat(Y) (layanan, harga, letak, \& lengkap). terhadap kepuasan masyarakat(Y) (layanan, harga, letak, \& lengkap)"

Ha : PYX2 = PYX4 \# 0 
Ho : PYX2 $=$ PYX4 $=0$

Dari hasil pengolahan data program SPSS 17 for windows terlihat pada table berikut, koefisien jalur yang diperoleh adalah :

ANOVA $^{\mathrm{b}}$

\begin{tabular}{|ll|l|l|l|l|l|}
\hline Model & & Sum of Squares & Df & Mean Square & F & Sig. \\
\hline 1 & Regression & 1542.060 & 2 & 771.030 & 17.903 & $.001^{\mathrm{a}}$ \\
& Residual & 387.607 & 9 & 43.067 & & \\
& Total & 1929.667 & 11 & & & \\
\hline
\end{tabular}

a. Predictors: (Constant), Mutu Lulusan (X4), Komponen Proses 2 (X2)

b. Dependent Variable: Kepuasan Masyarakat (Y)

Coefficients $^{\mathrm{a}}$

\begin{tabular}{|c|c|c|c|c|c|c|}
\hline \multirow{2}{*}{\multicolumn{2}{|c|}{ Model }} & \multicolumn{2}{|c|}{ Unstandardized Coefficients } & \multirow{2}{*}{ 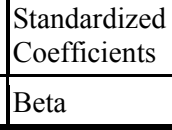 } & \multirow[b]{2}{*}{$\mathrm{t}$} & \multirow[b]{2}{*}{ Sig. } \\
\hline & & B & Std. Error & & & \\
\hline \multirow[t]{3}{*}{1} & (Constant) & -11.822 & 14.087 & & -.839 & .423 \\
\hline & Komponen Proses 2 (X2) & -.096 & .233 & -.110 & -.413 & .690 \\
\hline & Mutu Lulusan (X4) & 1.151 & .313 & .983 & 3.677 & .005 \\
\hline
\end{tabular}

a. Dependent Variable: Kepuasan Masyarakat (Y)

Model Summary

\begin{tabular}{|c|c|c|c|c|c|c|c|c|c|}
\hline \multirow[b]{2}{*}{ Model } & \multirow[b]{2}{*}{$\mathrm{R}$} & \multirow[b]{2}{*}{ R Square } & \multirow[b]{2}{*}{$\begin{array}{l}\text { Adjusted R } \\
\text { Square }\end{array}$} & \multirow[b]{2}{*}{$\begin{array}{l}\text { Std. Error } \\
\text { of the } \\
\text { Estimate }\end{array}$} & \multicolumn{5}{|c|}{ Change Statistics } \\
\hline & & & & & $\begin{array}{c}\mathrm{R} \\
\text { Square } \\
\text { Change }\end{array}$ & $\begin{array}{c}\mathrm{F} \\
\text { Chang } \\
\mathrm{e}\end{array}$ & df1 & $\mathrm{df} 2$ & Sig. F Change \\
\hline 1 & $.894^{\mathrm{a}}$ & .799 & .754 & 6.56258 & .799 & 17.903 & 2 & 9 & .001 \\
\hline
\end{tabular}

a. Predictors: (Constant), Mutu Lulusan (X4), Komponen Proses 2 (X2)

Tabel anova diperoleh nilai $\mathrm{F}$ untuk sebesar 17,903 dengan nilai probabilitas $(\operatorname{sig})=0,000$. Karena nilai sig $<0,05$, maka keputusannya adalah HO di tolak dan Ha diterima artinya komponen proses 2(X2) dengan Mutu Lulusan (X4) secara bersama-sama berpengaruh terhadap Kepuasan Masyarakat (Y). 
Besarnya koefisien determinan $\mathrm{R}_{\text {square }}$ atau $\mathrm{R}^{2}$ yx1x4 $=0,799=79,9 \%$ (lihat tabel summary) dan dan besarnya pengaruh variable lain pye1 $=\sqrt{-0,799}=0,201=$ $20,1 \%$.

\section{c) Hipotesis 3}

Terdapat kontribusi komponen proses 3(X3) (lingkungan, dana, kepemimpinan, \& manajemen) melalui mutu lulusan(X4) (kepercayaan, loyalitas \& komitmen) terhadap kepuasan masyarakat(Y) (layanan, harga, letak, \& lengkap). terhadap kepuasan masyarakat(Y) (layanan, harga, letak, \& lengkap)"

$$
\begin{aligned}
& \text { Ha }: \text { PYX3 = PYX4 \# } 0 \\
& \text { Ho }: \text { PYX3 }=\text { PYX4 = }
\end{aligned}
$$

Dari hasil pengolahan data program SPSS 17 for windows terlihat pada table berikut, koefisien jalur yang diperoleh adalah :

$$
\text { ANOVA }^{\mathrm{b}}
$$

\begin{tabular}{|ll|l|l|l|l|l|}
\hline Model & & Sum of Squares & df & Mean Square & F & Sig. \\
\hline 1 & Regression & 1654.364 & 2 & 827.182 & 27.042 & $.000^{\mathrm{a}}$ \\
& Residual & 275.303 & 9 & 30.589 & & \\
& Total & 1929.667 & 11 & & & \\
\hline
\end{tabular}

a. Predictors: (Constant), Mutu Lulusan (X4), Komponen Proses 3 (X3)

\begin{tabular}{|c|c|c|c|c|c|c|}
\hline \multirow{2}{*}{\multicolumn{2}{|c|}{ Model }} & \multicolumn{2}{|c|}{ Unstandardized Coefficients } & \multirow{2}{*}{\begin{tabular}{|l}
$\begin{array}{l}\text { Standardized } \\
\text { Coefficients }\end{array}$ \\
Beta
\end{tabular}} & \multirow[b]{2}{*}{$\mathrm{t}$} & \multirow[b]{2}{*}{ Sig. } \\
\hline & & B & Std. Error & & & \\
\hline \multirow[t]{3}{*}{1} & (Constant) & -7.507 & 10.772 & & -.697 & .503 \\
\hline & Komponen Proses 3 (X3) & .597 & .302 & .452 & 1.978 & .079 \\
\hline & Mutu Lulusan (X4) & .603 & .267 & .515 & 2.255 & .051 \\
\hline
\end{tabular}

b. Dependent Variable: Kepuasan Masyarakat (Y)

Coefficients $^{\mathrm{a}}$

\begin{tabular}{|c|c|c|c|c|c|c|c|c|c|}
\hline \multirow[b]{2}{*}{ Model } & \multirow[b]{2}{*}{$\mathrm{R}$} & \multirow[b]{2}{*}{ R Square } & \multirow{2}{*}{$\begin{array}{l}\text { Adjusted } \\
\text { R Square }\end{array}$} & \multirow{2}{*}{$\begin{array}{l}\text { Std. Error of } \\
\text { the Estimate }\end{array}$} & \multicolumn{5}{|c|}{ Change Statistics } \\
\hline & & & & & $\begin{array}{l}\text { R Square } \\
\text { Change }\end{array}$ & F Change & df1 & df2 & $\begin{array}{l}\text { Sig. F } \\
\text { Change }\end{array}$ \\
\hline 1 & $.926^{\mathrm{a}}$ & .857 & .826 & 5.53075 & .857 & 27.042 & 2 & 9 & .000 \\
\hline
\end{tabular}

a. Dependent Variable: Kepuasan Masyarakat (Y)

Model Summary

a. Predictors: (Constant), Mutu Lulusan (X4), Komponen Proses 3 (X3) 
Tabel anova diperoleh nilai $\mathrm{F}$ untuk sebesar 27,042 dengan nilai probabilitas $(\mathrm{sig})=0,000$. Karena nilai sig $<0,05$, maka keputusannya adalah $\mathrm{HO}$ di tolak dan Ha diterima artinya komponen proses 3(X3) dengan Mutu Lulusan (X4) secara bersama-sama berpengaruh terhadap Kepuasan Masyarakat (Y).

Besarnya koefisien determinan $\mathrm{R}_{\text {square }}$ atau $\mathrm{R}^{2} \mathrm{yx} 1 \mathrm{x} 4=0,857=85,7 \%$ (lihat tabel summary) dan dan besarnya pengaruh variable lain $p_{\text {ye1 }}=\sqrt{-0,057}=0,143=$ $14,3 \%$.

\section{A. Pembahasan}

1. Hipotesis pertama yang menyatakan terdapat kontribusi komponen proses 1(X1) (kurikulum, silabus, \& pembelajaran) melalui mutu lulusan(X4) (kepercayaan, loyalitas \& komitmen) terhadap kepuasan masyarakat(Y) (layanan, harga, letak, \& lengkap) bahwa memang secara bersama-sama memiliki nilai signifikan. Artinya dapat dikatakan bahwa komponen proses 1 yang terdiri dari kurikulum, silabus dan pembelajaran berpengaruh terhadap mutu lulusan dan sekaligus keduanya memiliki konstribusi yang positif dan signifikan terhadap persepsi masyarakat dalam kepuasan melihat outcome sebuah perguruan tinggi Islam.

2. Hipotesis kedua yang menyatakan terdapat kontribusi komponen proses 2(X2) (dosen, mahasiswa, \& fasilitas) melalui mutu lulusan(X4) (kepercayaan, loyalitas \& komitmen) terhadap kepuasan masyarakat(Y) (layanan, harga, letak, \& lengkap) bahwa memang secara bersama-sama memiliki nilai signifikan. Artinya dapat dikatakan bahwa komponen proses 2 yang terdiri dari dosen, mahasiswa, dan fasilitas berpengaruh terhadap mutu lulusan dan sekaligus keduanya memiliki kontribusi yang positif dan signifikan terhadap persepsi masyarakat dalam kepuasan melihat outcome sebuah perguruan tinggi Islam.

3. Hipotesis ketiga yang menyatakan terdapat kontribusi komponen proses 3(X3) (lingkungan, dana, kepemimpinan, \& manajemen) melalui mutu lulusan(X4) (kepercayaan, loyalitas \& komitmen) terhadap kepuasan masyarakat(Y) (layanan, harga, letak, \& lengkap) bahwa memang secara 
bersama-sama memiliki nilai signifikan. Artinya dapat dikatakan bahwa komponen proses 3 yang terdiri dari lingkungan, dana, dan manajemen berpengaruh terhadap mutu lulusan dan sekaligus keduanya memiliki kontribusi yang positif dan signifikan terhadap persepsi masyarakat dalam kepuasan melihat outcome sebuah perguruan tinggi Islam.

\section{KESIMPULAN}

1. Hipotesis pertama yang menyatakan terdapat kontribusi komponen proses 1(X1) (kurikulum, silabus, \& pembelajaran) melalui mutu lulusan(X4) (kepercayaan, loyalitas \& komitmen) terhadap kepuasan masyarakat(Y) (layanan, harga, letak, \& lengkap) bahwa memang secara bersama-sama memiliki nilai signifikan. Artinya dapat dikatakan bahwa komponen proses 1 yang terdiri dari kurikulum, silabus dan pembelajaran berpengaruh terhadap mutu lulusan dan sekaligus keduanya memiliki konstribusi yang positif dan signifikan terhadap persepsi masyarakat dalam kepuasan melihat outcome sebuah perguruan tinggi Islam.

2. Hipotesis kedua yang menyatakan terdapat kontribusi komponen proses 2(X2) (dosen, mahasiswa, \& fasilitas) melalui mutu lulusan(X4) (kepercayaan, loyalitas \& komitmen) terhadap kepuasan masyarakat(Y) (layanan, harga, letak, \& lengkap) bahwa memang secara bersama-sama memiliki nilai signifikan. Artinya dapat dikatakan bahwa komponen proses 2 yang terdiri dari dosen, mahasiswa, dan fasilitas berpengaruh terhadap mutu lulusan dan sekaligus keduanya memiliki kontribusi yang positif dan signifikan terhadap persepsi masyarakat dalam kepuasan melihat outcome sebuah perguruan tinggi Islam.

3. Hipotesis ketiga yang menyatakan terdapat kontribusi komponen proses 3(X3) (lingkungan, dana, kepemimpinan, \& manajemen) melalui mutu lulusan(X4) (kepercayaan, loyalitas \& komitmen) terhadap kepuasan masyarakat(Y) (layanan, harga, letak, \& lengkap) bahwa memang secara bersama-sama memiliki nilai signifikan. Artinya dapat dikatakan bahwa 
komponen proses 3 yang terdiri dari lingkungan, dana, dan manajemen berpengaruh terhadap mutu lulusan dan sekaligus keduanya memiliki kontribusi yang positif dan signifikan terhadap persepsi masyarakat dalam kepuasan melihat outcome sebuah perguruan tinggi Islam.

\section{Daftar Pustaka}

Amir, M. Taufik. 2005. Edisi Pertama. Dinamika Pemasaran Jelajahi dan Rasakan. Jakarta: PT Raja Grafindo Persada

Barnes, James G. 2003. Secrets of Customer Relationship Management (Rahasia Manajemen Hubungan Pelanggan). Yogyakarta: Andi

Dharmmesta, Basu Swasta dan Hani Handoko. Edisi Pertama. 1997. Manajemen Pemasaran Analisa Perilaku Konsumen. Yogyakarta: BPFE

Engel, James F. Roger, D. Blacwell. and Minsard, Paul W. 1994. Perilaku Konsumen. Jakarta

Gerson, Richard F. 2002. Mengukur Kepuasan Pelanggan. Jakarta: Penerbit PPM

Jerome E, dkk. Edisi Ke-lima. 1993. Dasar-Dasar Pemasaran. Jakarta: Erlangga

Kotler, Philip. 2002. Edisi Milenium. Manajemen Pemasaran. Jakarta: PT Prenhalindo

Lupiyoadi, Rambat. 2001. Edisi Pertama. Manajemen Pemasaran Jasa: Teori dan Praktik. Jakarta: Salemba Empat

Nasution, M. Nur. 2004. Manajemen Jasa Terpadu. Bogor: Ghalia Indonesia Bainarupa Aksara

Pamitra, Teddy. 2001. Perilaku Konsumen dan Komunikasi Pemasaran. Bandung: PT Remaja Rosda Karya.

Peter, J. Paul dan Jerry C Olson. 1996. Edisi Keempat. Consumer Behavior (perilaku konsumen dan strategi pemasaran). Jakarta: Erlangga

Purnomo, Hari. 2003. Edisi Pertama. Pengantar Tehnik Industri. Yogyakarta: Penerbit Graha Ilmu

Supranto, J. 2001. Pengukuran Tingkat Kepuasan Pelanggan. Jakarta: PT Asdi Mahasatya.

Umar, Husein. 2003. Metode Riset Perilaku Konsumen Jasa. Jakarta: Gholia Indonesia 